\title{
Bilateral acute iris transillumination (BAIT) initially misdiagnosed as acute iridocyclitis
}

\author{
Transiluminação de íris aguda bilateral (BAIT) inicialmente diagnosticada como iridociclite aguda
}

Saban Gonul ${ }^{1}$, Banu Bozkurt ${ }^{1}$

\begin{abstract}
Bilateral acute iris transillumination (BAIT) is a relatively new clinical entity characterized by bilateral acute loss of iris pigment epithelium, iris transillumination, pigment dispersion in the anterior chamber, and sphincter paralysis. We report the case of a 30-year-old male who was initially diagnosed with acute iridocyclitis in a different clinic and treated with topical and systemic corticosteroids. He was referred to our clinic to seek another opinion because his symptoms did not improve. An ocular examination revealed bilateral pigment dispersion into the anterior chamber diffuse iris transillumination, pigment dusting on the anterior lens capsule, atonic and distorted pupils, and increased intraocular pressure, suggesting a diagnosis of BAIT rather than iridocyclitis. Clinicians should be aware of the differential diagnosis of syndromes associated with pigment dispersion from iridocyclitis to avoid aggressive anti-inflammatory therapy and detailed investigation for uveitis.
\end{abstract}

Keywords: Iris diseases/diagnosis; Pigment epithelium of eye/pathology;Transillumination; Iridocyclitis/diagnosis; Diagnosis, differential; Case reports

\section{RESUMO}

A transiluminação de íris aguda bilateral (do inglês, bilateral acute iris transillumination, BAIT) é uma entidade clínica relativamente nova, caracterizada pela perda aguda bilateral do epitélio pigmentado da íris, transiluminação iriana, dispersão de pigmentos na câmara anterior, e paralisia do esfíncter pupilar. Nós relatamos o caso de um homem de 30 anos que foi diagnosticado com iridociclite aguda e tratado com corticosteroides tópicos e sistêmicos. Ele foi encaminhado ao nosso serviço para outra opinião, porqueseus sintomas não melhoram com a terapia. Um exame oftalmológico revelou dispersão bilateral de pigmentos para a câmara anterior, transiluminação difusa de íris, pigmento difusa na cápsula anterior do cristalino, pupilas atônicas e distorcidas, e um aumento da pressão intraocular, o que sugere um diagnóstico de BAIT em vez de iridociclite. Os médicos devem estar cientes do diagnóstico diferencial das síndromes associadas à dispersão de pigmento com a iridociclite para evitar a terapia antiinflamatória agressiva e investigação detalhada para uveíte.

Descritores: Doenças da íris/diagnóstico; Epitélio pigmentado ocular/patologia; Transiluminação; Iridociclite/diagnóstico; Diagnóstico diferencial; Relatos de casos

\section{INTRODUCTION}

Bilateral acute iris transillumination (BAIT) is a very rare condition characterized by the bilateral acute loss of iris pigment epithelium, iris transillumination, pigment showering, persistent mydriasis, and occasional increased intraocular pressure $(I O P)^{(1,2)}$. Patients with BAIT generally present with acute ocular pain, photophobia, and red eyes ${ }^{(1)}$, which are also observed in patients with iridocyclitis. Furthermore, the circulating pigment particles in the anterior chamber may be confused with the inflammatory cells seen in patients with iridocyclitis. Therefore, the presenting symptoms and findings of BAIT may result in a misdiagnosis of acute iridocyclitis. We report a case of BAIT in a patient who was initially misdiagnosed with iridocyclitis and treated with corticosteroid therapy.

\section{CASE REPORT}

A 30-year-old male was referred to our clinic to seek another opinion for his diagnosed iridocyclitis, which was unresponsive to treatment. Two months previously, he had been admitted to another clinic with acute bilateral ocular pain, severe photophobia, and red eyes. He was diagnosed with iridocyclitis and treated with topical and systemic corticosteroids. However, his signs and symptoms did not improve. The patient also had a history of upper respiratory tract infection and use of the systemic cefazolin 3 months previously. On admission, his best-corrected visual acuity was 20/20 in both eyes. Slit-lamp examination revealed bilateral conjunctival hyperemia, 1+ circulating pigment in the anterior chamber, diffuse iris transillumination, pigment dusting on the anterior lens capsule, and mydriatic and distorted pupils (Figures 1 A, B and 2 A, B). There were no inflammatory keratic precipitates on the corneal endothelium or inflammatory cells in the anterior vitreous of either eye. Corneal sensation was intact in both eyes. Gonioscopy showed heavy pigment deposition in the trabecular meshwork bilaterally (Figure 2 C, D). There was no evidence of posterior iris bowing or peripheral anterior synechiae on the gonioscopy. IOP was $20 \mathrm{mmHg}$ in the right eye and $18 \mathrm{mmHg}$ in the right eye. The fundus examination was normal in both eyes. The patient had undergone a complete laboratory evaluation for uveitis in the other clinic. The results of those tests, including erythrocyte sedimentation rate, complete blood cell count, biochemistry, urinalysis, venereal disease research laboratory test, intradermal purified protein derivative test, and computed tomography of the chest, were normal. Human leukocyte antigen-B51 (HLA-B51) and HLA-B27 were negative.

On admission to our clinic, the patient was using topical prednisolone acetate 1\% 8 times a day, topical cyclopentolate 1\% twice a day, and a fixed carbonic anhydrase inhibitor/beta blocker combination. The cyclopentolate was discontinued, and the prednisolone was
Funding: No specific financial support was available for this study

Disclosure of potential conflicts of interest: None of the authors have any potential conflict of interest to disclose.

Corresponding author: Saban Gonul. Selcuk University Faculty of Medicine - Department of Ophthalmology - Konya - Turkey - E-mail: drsabangonul@gmail.com 

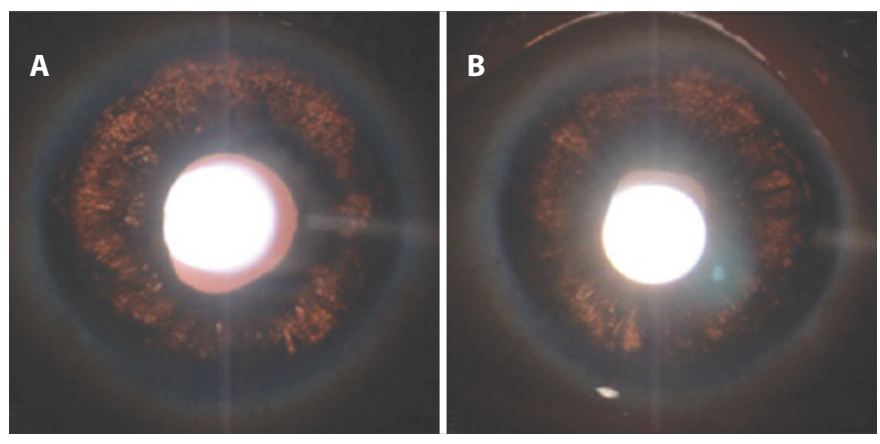

Figure 1. Slit-lamp photographs of right $(\mathrm{A})$ and left $(\mathrm{B})$ eyes showing diffuse iris transillumination defects using the retroillumination technique. The photographs were taken without pharmacologic dilation of the pupils.
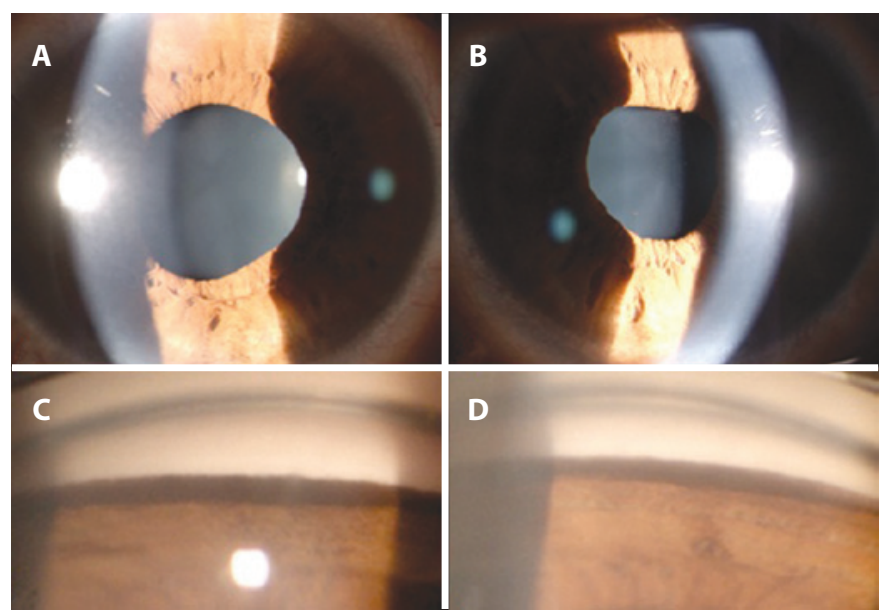

Figure 2. Slit-lamp photographs of right (A) and left (B) eyes showing mydriatic, distorted pupils with poor response to light, and a small amount of pigment dusting on the anterior lens capsule. Gonioscopy of right (C) and left (D) inferior angles showing heavy inferior trabecular meshwork pigmentation.

tapered and discontinued after a month. The patient remained stable for the rest of his 3-month follow-up, without the need for steroid treatment. During follow-up examinations, IOP did not increase, the pigment dispersion in the anterior chamber decreased, and the iris transillumination defects remained stable.

\section{DISCUSSION}

Iris atrophy with and without transillumination may be caused by several diseases, such as viral iridocyclitis, pigment dispersion syndrome (PDS), pseudoexfoliation syndrome, Fuchs uveitis syndrome (FUS), Vogt-Koyanagi-Harada disease, acute angle-closure glaucoma, ocular trauma, bilateral acute depigmentation of the iris (BADI), and BAIT ${ }^{(1-5)}$.

The most common differential diagnosis in pigment dispersion and iris transillumination is PDS, which typically occurs in young myopic adults. It is usually asymptomatic and characterized by posterior bowing of the iris, Krukenberg's spindle, and slit-like, radial, midperipheral transillumination defects ${ }^{(6)}$, none of which were detected in our patient.

Herpes simplex and cytomegalovirus may cause unilateral iridocyclitis with sectorial/diffuse iris atrophy and transillumination. Although an aqueous tap for polymerase chain reaction (PCR) analysis is requi- red for a definite diagnosis, negative results do not exclude a viral etiology ${ }^{(7)}$. We were unable to obtain aqueous humor for viral analysis, because the patient did not consent to the procedure. However, symmetrical and bilateral involvement, lack of keratic precipitates, and atonic pupils with compromised reaction to light helped us to differentiate BAIT from viral uveitis.

FUS is a chronic, asymptomatic, low-grade unilateral uveitis characterized by diffuse, stellate, and medium-sized keratic precipitates and iris stromal atrophy, with or without heterochromia, and without posterior synechiae(8), which were also not detected in the present case.

Our patient displayed the clinical findings of BAIT, including acute onset of severe photophobia and red eyes, bilateral severe transillumination of the iris, pigment showering in the anterior chamber, a mydriatic and distorted pupils, and increased IOP. This condition should also be differentiated from BADI, which has a more benign course and shorter duration of pigment discharge, a lower incidence of elevated IOP, which is transient, and reversibility of iris changes in some patients $s^{(5)}$. Both conditions have a common etiology but the pigment discharge seems to be only from the iris pigment epithelium in BAIT and from the iris stroma in BADI. The features that differentiate BADI from BAIT are depigmentation of the iris without transillumination defect and unaffected pupils ${ }^{(1)}$.

BAIT may also masquerade as iridocyclitis, as in the case of our patient, who was referred for evaluation of bilateral acute iridocyclitis. On our initial examination, he had no inflammatory keratic precipitates on the corneal endothelium but had all of the clinical findings of BAIT. Therefore, we ruled out acute iridocyclitis.

Although the exact etiopathogenesis of BAIT remains unclear, several publications have reported a relationship between BAIT and systemic use of moxifloxacin ${ }^{(2)}$ and clarithromycin ${ }^{(9)}$, upper respiratory tract infections ${ }^{(1)}$, and a toxic effect following fumigation ${ }^{(10)}$. Our patient had a history of upper respiratory tract infection and use of systemic cefazolin 3 weeks before the onset of his symptoms. It is difficult to establish which of those factors was the cause of BAIT. Tugal-Tutkun et al. ${ }^{(1)}$ reported 26 patients with BAIT, 19 of whom had a history of upper respiratory tract infection and use of systemic antibiotics, including moxifloxacin, ampicillin/sulbactam, amoxicillin/ clavulanate, trimethoprim/sulfamethoxazole, cefixime, and penicillin V. However, they concluded that the relationship between BAIT and systemic antibiotic use was coincidental, because there are no reported ocular adverse effects related to the topical use of these antibiotics, in particular moxifloxacin, which has efficient ocular penetration. We use moxifloxacin in the anterior chamber for prophylaxis of endophthalmitis after cataract surgery, and we have not encountered any cases of BAIT associated with its use. Therefore, it appears that BAIT in the present case was triggered by the virus that caused the upper respiratory tract infection.

In conclusion, BAIT should be differentiated from other diseases causing pigment dispersion into the anterior chamber and from iridocyclitis. It is important to make a correct differential diagnosis of BAIT from anterior uveitis to avoid the unnecessary use of corticosteroids and detailed investigation for uveitis. Early diagnosis of this condition is also important because of the risk of marked increases in IOP.

\section{REFERENCES}

1. Tugal-Tutkun I, Onal S, Garip A, Taskapili M, Kazokoglu H, Kadayifcilar S, et al. Bilateral acute iris transillumination. Arch Ophthalmol. 2011;129(10):1312-19.

2. Morshedi RG, Bettis DI, Moshirfar M, Vitale AT. Bilateral acute iris transillumination following systemic moxifloxacin for respiratory illness: report of two cases and review of the literature. Ocul Immunol Inflamm. 2012;20(4):266-72.

3. Maestrini HA, Maestrini AA, Machado Dde O, Santos DV, Almeida HG. Bilateral acute depigmentation of the iris (BADI): first reported case in Brazil. Arq Bras Oftalmol. 2013; 76(1):42-4.

4. Tugal-Tutkun I, Urgancioglu M. Bilateral. Acute depigmentation of the iris. Graefes Arch Clin Exp Ophthalmol. 2006;244(6):742-6.

5. Tugal-Tutkun I, Araz B, Taskapili M, Akova YA, Yalniz-Akkaya Z, Berker N, et al. Bilateral 
acute depigmentation of the iris: report of 26 new cases and four-year follow-up of two patients. Ophthalmology. 2009:116(8):1552-7.

6. Niyadurupola N, Broadway DC. Pigment dispersion syndrome and pigmentary glaucoma: a major review. Clin Experiment Ophthalmol. 2008;36(9):868-82.

7. De Groot-Mijnes JD, Rothova A, van Loon AM, Schuller M, Ten Dam-Van Loon NH, De Boer JH, et al. Polymerase chain reaction and Goldmann-Witmer coefficient analysis are complimentary for the diagnosis of infectious uveitis. Am J Ophthalmol. 2006 141(2):313-8.
8. Mohamed Q, Zamir E. Update on Fuchs' uveitis syndrome. Curr Opin Ophthalmol. 2005; 16(6):356-63.

9. Tranos P, Nasr MB, Asteriades S, Vakalis A, Georgalas I. iris Bilateral difusas atrofia após o uso de claritromicina oral. Cutan Ocul Toxicol. 2014;33(1):79-81.

10. Gonul S, Bozkurt B, Okudan S, Tugal-Tutkun I. Bilateral acute iris transillumination following a fumigation therapy: a village-based traditional method for the treatment of ophthalmomyiasis. Cutan Ocul Toxicol. 2014. [Epub ahead of print]. doi number: 10.3109/15569527.2014.886589

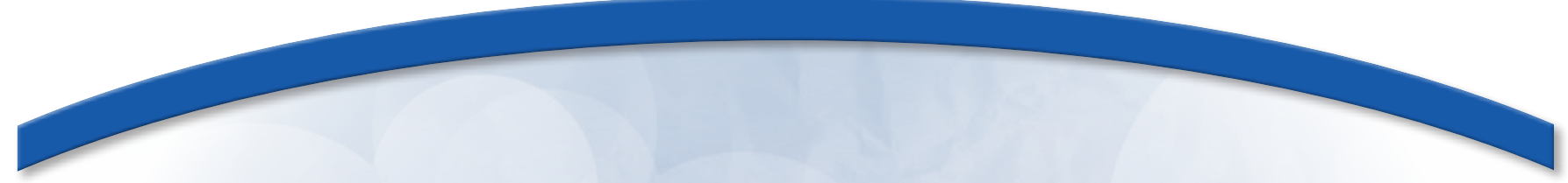

XVI Simpósio Internacional da Sociedade Brasileira de Glaucoma

\section{4 a 16 de maio de 2015}

Goiânia-GO

\section{Informações:}

E-mail: sbglaucoma@sbglaucoma.com

Site: www.sbglaucoma.com

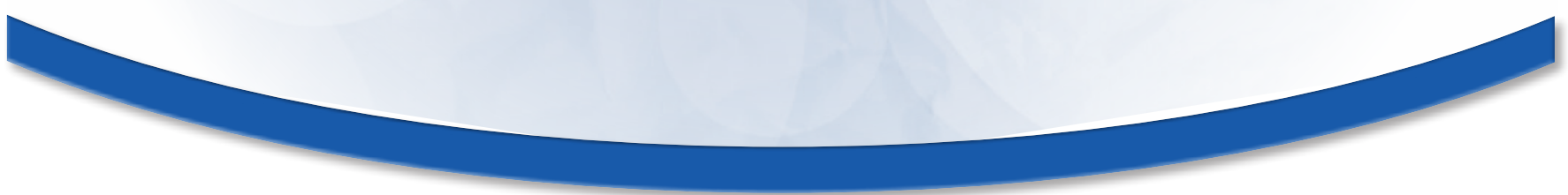

